\title{
The Readiness of Banyumas District in Investment Sector to Face Asean Economic Community 2015
}

\author{
Elpeni Fitrah \\ MA (Universitas Jenderal Soedirman) \\ (slametrosyadi72@gmail.com)
}

\author{
Ayusia Sabhita Kusuma \\ M.Soc.Sc (Universitas Jenderal Soedirman)
}

\begin{abstract}
This research seeks to analyze the readiness of Banyumas district, in Central Java Province, Indonesia facing the challenges of the ASEAN Economic Community, especially in the investment sector. The aim of this research is to see how local governments draw up strategies and programs in order to welcome the implementation of free flow of investment in the region as one of main pillar of ASEAN Economic Community. This research uses qualitative method with descriptiveinterpretative analysis technique, referring to primary and secondary data. The result of the research is the local government is ready to face the challenge of ASEAN Economic Community such as create regulations to give permission and license to several business sectors in investment programs in Banyumas, and also develop infrastructure to support the good investment environment.
\end{abstract}

Keywords-Banyumas District; Investment Sectors; ASEAN Economy Community; Investment licensing services; Infrastructure

\section{INTRODUCTION}

The enhancement of regional integration in Southeast Asia has been sought through the establishment of ASEAN Community in December 2015. The purpose of the establishment of ASEAN Community is to further strengthen, deepen and broaden ASEAN integration through people to people contact facing the challenge of the competitiveness in international economy and political constellation. ASEAN Community in 2015 was based on three pillars, namely Community ASEAN Political and Security (ASEAN Political Security Community), the ASEAN Economic Community (ASEAN Economic Community), and Socio-Cultural Community ASEAN (ASEAN Socio-Cultural Community) (ASEAN , 2009).

In economic field, the purpose of AEC outlined in the AEC Blueprint as follows; realizing the region's economy competitive, equitable economic development and to encourage full integration with the global economy (ASEAN, 2009). ASEAN Economic Community (AEC) itself has 5 pillars to boost economic regional integration to become a single market and high competitiveness production base. The five pillars as follows; free flow of goods, free flow of services, free flow of capital, free flow of investment, free flow of entrepreneurs and skilled labor.

The local region's economic development itself is an integral part to support national economic development.
Referring to the Act No. 32 of 2004, the local region was given the widest possible powers to regulate and manage their own territory and their available resources to improve the welfare of local communities. In this context, the area through local governments are required to prepare themselves to maximize the potential and advantages of the local region in the face of the ASEAN single market and capture opportunities as possible in order to compete with other regions in the entire Southeast Asian countries.

One of the main important pillar in AEC is the free flow of investment and capital in the region. Therefore, the local government and central government in Indonesia should work together to provide a good investment environment in order to compete in competitive trade market in the region. The local and central government should create the regulations, infrastructures, and good human resources to reach good investment environment. Banyumas, as a potencial district in central java province, has so many potential sectors to be developed. The domestic investors in Banyumas show an increasing number there is 384 investors in 2009 to 611 investors in 2013. The realizable value of domestic investment increased significantly in 2013 reached 589,016,435,717 billion rupiah from the achievement in the amount of $380,304,425$ million rupiah in 2009. The labors can be absorbed from that investment represents an improvement of as many as 3,309 people in 2009, to 7304 people in 2013. The increase in investment performance in Banyumas shows that investment in Banyumas had a pretty good performance (Bappeda, 2014).

This research is to analyze the readiness of Banyumas District to face ASEAN Economic Community through the regulations, the investors, the society and the resources in the investment sectors. Issues examined in this study is the extent to which government policy Banyumas supporting improvements in the investment sector facing the implementation of the ASEAN Economic Community by 2015. The next question is whether the government has done a comprehensive effort to strengthen the trade and investment sectors facing competition ASEAN Economic Community.

\section{RESEARCH METHOD}

This research is conducted using qualitative method. The data collection methods using primary data collection by doing in-depth interviews and secondary data collection through 
literatures study. Descriptive-interpretative analysis model is the analytical model used in the research.

\section{DISCUSSION}

\section{A. Regionalism in Southeast Asia through ASEAN Economic Community}

Mansbach (1973) conceived the region as a regional grouping identified on basis of geographical proximity, cultural trade and economic interdependence that is mutually beneficial, communication and participation in international organizations. Another definition says regionalism is a set of ideas that identify the geographic and social space as a regional project or it can be interpreted also as awareness building an identity which then formed a special region. Regionalism is often associated with the program policies (objectives) and strategies (means and mechanisms to achieve these objectives) which will usually lead to the establishment of the institution (Stubbs 2006).

Basically, regionalism is a form of interdependence which is set based on geographic proximity that can develop into a wide range of common interests. Therefore, regionalism is a necessary stage in the international community towards globalism aspired (Sjamsumar, 1995). ASEAN leaders declare Roadmap 2009-2015 that contains the Community Blue Prints: Economic (AEC), Politics-Security (APSC), Socio-Culture (ASCC) which is the basis of the ASEAN Community by 2015 The ASEAN Community aims to create a society that forwardlooking, living in an environment that is peaceful, stable and prosperous, united by dynamic partnerships and creating a community of caring.

One of main pillar ASEAN Community is ASEAN Economic Community. AEC is the realization of free trade in Southeast Asia that previously called in the Framework Agreement on Enhancing ASEAN Economic Cooperation in 1992. AEC has purpose to create a single market and production base in ASEAN in a dynamic and competitive way with new mechanisms and measures to strengthen the implementation of existing economic initiatives; accelerate regional integration in priority sectors; facilitating the movement of business people, skilled and talented workforce; and strengthen the institutional mechanisms of ASEAN.

The core of AEC summarized in the Five Pillars; first pillar is the Free Flow of Goods, it is a mechanism that allows the flow of goods to flow freely intra ASEAN countries. The second pillar is the Free Flow of Investment which is a free and open investment regime as the key to enhancing the competitiveness of ASEAN to attract foreign direct investment (FDI) and investment in intra ASEAN Countries. The third pillar is the Free Flow of Capital, it is a mechanism which allows the flow of free-flowing movement of capital within the scope of ASEAN. The fourth pillar is Free flow of skilled labor is a mechanism which allows the free movement of skilled labor will flow to fill industry sector in ASEAN. The fifth pillar is the Free Flow of Services is a mechanism that allows freedom and good public services in the ASEAN region.

\section{B. The Readiness of Local Region in Investment}

Free flow of investments and free flow of capital are two main factors in the formation of AEC. Basic definition of "investment" is the sacrifice of current consumption in order to increase consumption at a later date. Investment has two different forms, there are real investments, the purchase of physical capital to employ in a production process and increase profit. Meanwhile financial investment is the purchase of "paper" securities such as stocks and bonds (Myles, 2003:4-5). Investment activities increase the economic activities in society and open employment opportunity, increase local and national income and also increase people's welfare (Sukirno, 2000). In Indonesia, there are two types of investments; National Capital Investment and Foreign Investment or Foreign Direct Investment. The agency that giving permit to private national and foreign investment are addressed by Capital Investment Coordinating Board (Badan Koordinasi Penanaman Modal/BPKM). In Banyumas, investment affairs addressed by Board of Investment and Licensing Services (BPMPP).

Banyumas District Regulation Number 10 of 2013 on Regional Medium Term Development Plan in the year 20132018, mentioned that local government concern in the establishment of strategic areas in Banyumas for economic growth, social and cultural interests, exploitation of natural resources, high tech and the interests of the function and capacity of the environment ( Pemerintah Kabupaten Banyumas, 2013). Banyumas also made the Regional Regulation No. 2 of 2013 on Investment in Banyumas. In chapter 4 in the regulation mentioned that targets investments in Banyumas is to improve the investment environment; improve the supporting facilities investment; improve human resource capacity; increasing the number of investors; improve the investment realization and lower the unemployment rate. The local government also has plan to develop Banyumas into an industrial area and sought to be realized by 2020. Local government chooses some sub-district areas of potential to be used as an industrial area, such as Jatilawang, Purwojati, Wangon and Lumbir (Suara Merdeka, 2016).

The local government of Banyumas has efforts for the hospitality branding investment. This was done to attract investment to the potential product. Some material potential investments in Banyumas, among others; agri-food, tourism, nature-based traditional values, crystal sugar and livestock. Banyumas regency government is currently studying the possibility of developing tourism as the government already implemented several countries.

In order to increase investment realization too, Banyumas has developed an integrated one-stop licensing service organized by the Agency for Investment and Licensing Services.

Secretary Board of Investment and Licensing Services (BPMPP) Banyumas, Ahmad Suryanto, said local government support to SMEs in addition to improving the quality of human resources, the local government has the space to accommodate the handicraft products as well as processed Banyumas traditional dish. Banyumas has market called "Harsa Pratistha" Block A, which is used to market the products of Banyumas. 
Transaction service process has also been modern because using a computerized system (Suara Merdeka, 2015).

Local government of Banyumas through Board of Investment and Licensing Services (BPMPP) says that there are 577 permits data in investment is processed BPMPP Banyumas until the end of January 2016. Of that amount, 141 of them are trading license (original), both new and renewal. Besides trade, business permit applications are processed in BPMPP include industrial business licensing, construction services business, the restaurant business, a beauty parlor, and business hotel and lodging. (Suara Merdeka, 2016)

Some efforts in infrastructure sectors have been made by the Regional Government of Banyumas regency especially the Regional Spatial Planning Coordinating Board of Banyumas as an effort to prepare to face the AEC, there are:

1) Make a draft policy in Development, Maintenance and Expansion of Regional Roads in Banyumas regency that includes:

1. Development of Primary Arterial roads with the status of national Road totalling 6 roads.

2. The improvement of Primary Collector Roads with the status of national roads totaling 16 roads

3. Development of 8 Primary Collector Road and/or Strategic Provincial Roads.

4. The improvement and development of the road with the status of District roads totaling 7 roads.

2) Make a draft policy in Development, Maintenance and Expansion of Passenger Terminal in Banyumas regency that includes:

1. Development of Type A passenger terminal in Purwokerto Cities.

2. Type B passenger terminal development in the district and sub-district Ajibarang Wangon.

3. The development of the passenger terminal in Lima District of Type C.

3) Make a draft policy in Development, Maintenance and Expansion of Terminal of Goods in Banyumas regency that includes:

1. Development of Goods Terminal at sub-district Patikraja, Ajibarang, Wangon, and Kemranjen.

2. The provision of integrated goods terminal with Notog station in Sub-district Patikraja.

\section{CONCLUSION}

The readiness of local government of Banyumas district could seen through several programs that have been held, which are; make regulations to support the influx of investment to Banyumas; gave permission and license to the investment of several business and trading sectors; develop the infrastructures to support investors; increase the local products, potency and resources.

The local government should increase the confidence of investors to invest in the region. There are some things that should be considered by the Government of Banyumas in creating a conducive investment climate: First, enhance the productive regional egoism. This is a term used to describe the position of the local communities in the global competition; whether it be an object or subject. People that engaged in free trade situation should have the mindset to not be the workers in their own country. The local government needs to make efforts related to develop community capacity building. The form of increased capacity is the capacity of self-improvement, business capacity and capacity output (goods and services).

Second, Strengthen the capacity of entrepreneurs' organizations. Those organizations actually have a strategic role in developing the pace of investment and also the readiness of business actors themselves in the face of the MEA. The entrepreneurs' organizations need to enhance communication and good networking to share experiences and knowledge about trade and investment. The entrepreneurs organizations should strengthening organizational capacity building, especially in the management of the business, whether through an intensive communication as well as through the provision of education and training.

Third, build a mutually beneficial partnership among the entrepreneurs, investors, local government and the societies. Facing a high competition market in Southeast Asian region, local business sectors should work together with local government and local citizens in order to improve regional competitiveness.

\section{REFERENCES}

[1] Association Southeast Asian Nations. 2009. Roadmap for an ASEAN Community 2009-2015. Jakarta: ASEAN Secretariat

[2] Badan Perencanaan dan Pembangunan Daerah. Kab. Banyumas.2014. Kerangka Acuan Kerja. (unpublished)

[3] Hopkins R.F \& Mansbach. R.W. 1973. Structure and Process in International Politics New York: Harper and Row.

[4] Pemerintah Kabupaten Banyumas. 2013. Peraturan Daerah Kabupaten Banyumas No 7 Tahun 2009 tentang RPJMD Kab. Banyumas 20052025. Banyumas: Pemerintah Kabupaten Banyumas

[5] Sjamsumar Dam \& Riswadi. 1995. Kerjasama ASEAN. Jakarta: Ghalia Indonesia.

[6] Stubbs R \& Underhill G. 2006. Political Economy and the Changing Global Order. Oxford: Oxford University Press.

[7] Sukirno, Sadono. 2000. Makroekonomi Modern: Perkembangan Pemikiran dari Klasik Hingga Keynessian Baru. Jakarta: PT Grafindo Persada.

[8] Suara Merdeka, Sektor Perdagangan Mendominasi, March 16, 2016, \{http://berita.suaramerdeka.com/smcetak/sektor-perdaganganmendominasi/ $\}$ accessed on March 92016

[9] Suara Merdeka, Investor tertarik Kembangkan Bisnis di Banyumas, February 27 2015, \{http://berita.suaramerdeka.com/bisnis/investortertarik-kembangkan-bisnis-di-banyumas/\}accessed on March 82016 